актів, які регламентували суспільні відносини у цій сфері, встановлювали відповідну організаційно-правову модель, завдання для іiі суб'єктів та наділяли державні органи відповідним обсягом повноважень. Водночас, подальша імплементація положень спеціальних законодавчих актів у відповідне законодавство у повному обсязі проведена не була, що зумовлювалось зміною політичних пріоритетів, насамперед унаслідок діяльності п'ятої коаліції 6-го скликання Верховної Ради України і результатів президентських виборів 2010 року.

DOI https://doi.org/10.30525/978-9934-588-92-1-8

\title{
ДЕРЖАВНО-ПРАВОВА ІДЕОЛОГІЯ МОНГОЛЬСЬКОЇ ІМПЕРІЇ (1206-1279) ЯК ПРЕДТЕЧА РОСІЙСЬКОГО ЕКСПАНСІОНІЗМУ
}

\author{
Іванов О. Ю. \\ кандидат юридичних наук, \\ старший викладач кафедри теорії та історії держави і права \\ Національної академії Служби безпеки України \\ м. Київ, Украӥна
}

Невід'ємною ознакою розвитку сучасного міжнародного правопорядку є його глобалізація. У зв'язку з цим на стан його забезпечення безпосередньо впливають особливості правової ідеології та політики в окремих регіонах. Останні спрямовані головним чином на забезпечення міжнародної безпеки, проте в окремих випадках виступають i джерелами формування викликів для неї. 3-поміж них одне із найважливіших місць посідає Російська Федерація (далі - РФ) зі своєю агресивною зовнішньою політикою, котра, серед іншого, безпосередньо загрожує реалізації національних інтересів нашої держави. Геополітичний курс РФ базується на ідеологічних постулатах, що мають глибоке історичне коріння і були характерними ще для Московського царства, Російської імперії та радянської Росії. Виходячи 3 цього, для цілісного розуміння сучасної ситуації, особливо в контексті оцінки російського фактора в парадигмі забезпечення державної безпеки України, доцільним видається висвітлення історико-правових аспектів формування зовнішньої політики РФ.

Історія свідчить, що становлення експансіоністських основ російської державницької ідеології пов'язано з оформленням концепції 
«Москва - Третій Рим» на межі XV-XVI ст.ст. Зароджена на тлі падіння Візантійської імперії в 1453 р., вона відобразила прагнення московських правителів у контексті нібито прагнення до відродження величі останньої обгрунтувати свої претензії на світове панування. Окрім того, слід брати до уваги, що в період 1325-1480 pр. московські князі правили на підставі ярликів від ханів Золотої Орди. Поряд із формальним підпорядкуванням, Московське князівство сприймало також і ті традиції державного управління, адміністративного устрою та правового регулювання, котрі мали місце у державі - спадкоємиці Монгольської імперії. Насамперед, це стосувалося державницької ідеології, спрямованої на ведення переважно завойовницької зовнішньої політики та утримання свого населення в постійному стані страху та покори. Очевидною видається подібність цього принципу 3 тими, на яких базується політика сучасної РФ, а тому постає необхідність у виявленні механізмів проникнення відповідних ідеологічних установок у політичне середовище Московського царства.

Сучасні дослідники історії Золотої Орди, особливо західні, акцентують увагу на тому, що іiі адміністративна система вбирала в себе кращі зразки управління від завойованих територій, була такою собі «розумною системою», покликаною безперебійно забезпечувати централізацію влади в державі. При цьому враховувались особливості розвитку доволі розрізнених в етнічному та культурному плані земель. Загалом же Золота Орда як окремішне політичне формування утворилася в ході міжусобної боротьби в Монгольській імперії, що запанувала після смерті ії творця Темучжина (Чинхісхана) в 1227 р. Позаяк саме золотоординські правителі стали позиціонувати себе спроможними під своєю владою відродити колишню велич імперії Чингісхана, то ними була сприйнята й уся ідеологічна основа іiі державно-правового ладу. 3 огляду на те, що монгольська ідеологія по суті стала частиною державницької концепції Золотої Орди, то, відповідно, вона мала й опосередкований, проте значний вплив на суспільно-політичні процеси в Московському князівстві за доби його перебування у васальній залежності від ханів протягом 1325-1480 pp. Слід брати до уваги, що наслідки цього впливу стали відчутними і в більш пізні періоди існування московської держави, а потім Російської імперії і радянської Росії. Багато хто 3 науковців та політологів порівнює і сучасну РФ зі східною деспотією. Зазначене доводить, що розуміння сутності російської державницької ідеології без урахування монгольської виглядатиме неповно.

Будучи проголошеним «ханом над ханами» на Курултаї, що зібрався на річці Онон у 1206 р., Чингісхан узявся до формування сильної 42 
централізованої влади в державі. Саме 3 цією метою за його наказом було складено «Ясу» - збірник монгольських звичаїв, який відображав різноманітні аспекти життя країни з огляду на ії воєнізований характер. Основною його метою було неодмінне утвердження всеохоплюючої влади хана, непорушності та святості його розпоряджень, що забезпечувалося завдяки системі жорстких і невідворотних покарань. Адміністративний устрій і все життя в імперії загалом були організовані за принципом побудови гігантського воєнізованого підрозділу, який за необхідності будь-якої миті можна було би привести до стану повної бойової готовності. Великому ханові сучасники приписували такий вислів: «Я завжди попереду війська під час навчань і ніколи позаду - під час бою» [1]. Цим він визнавав поєднання у своїй особі вищої державної влади та функцій верховного воєначальника i, відповідно, симбіоз державного устрою та воєнної організації в Монгольській імперії. Істотно, що в одному з відомих історикам указів Чингісхана визначалася сутність його держави. Так, великий хан проголошував, що монголи до часу занепаду своєї держави мають підпорядкувати собі весь світ і не повинні перебувати в мирі ні 3 яким народом, який не забажає добровільно їм підкоритися [2]. По суті, йшлося про те, що саме в цьому і полягав сенс існування держави монголів: за рахунок завоювань вона повинна була існувати весь час аж до свого падіння.

Обожнювання правителя як базовий принцип монгольської ідеології було згодом покладено в основу концепції «Москва - Третій Рим» фундаменту московської, а потім і російської державницької ідеології. Так, до нас дійшли такі слова Чингісхана: «Бог - на Небі. Ха-хан Могутність Божа на Землі. Вічно Синє Небо повеліло мені правити всіма народами». Висловлені в них ідеї суголосні 3 китайською концепцією «тянь-мін» - «Мандат Неба» [3]. Відповідно до згаданої концепції, правитель держави вважався призначеним вищими силами, а дії його - заздалегідь ними санкціонованими i такими, що не потребують узгодження ні з чим і ні з ким. Виходячи із зазначеного, будь-який виступ проти волі правителя та прийнятих ним рішень, хай навіть і відверто незаконних, розглядається як посягання на вищі сили, позиціонування себе «розумнішим» від божества. Це охоплює також і сферу міжнародних відносин, передбачаючи, що монарх у своїх рішеннях не має необхідності враховувати інтереси інших держав чи загальні правила міждержавного співжиття. Позаяк у 1209 р. відбулося завоювання Китаю монголами 3 облаштуванням другої ставки хана в Пекіні, то місцева ідеологія також стала здобутком завойовників. Разом 3 тим, колоніальна експансія Монгольської імперії базувалася на тому, що центр ії культурно й економічно був почасти менш розвиненим 
порівняно із тими територіями, які підлягали завоюванню. У зв'язку з цим кращі досягнення їхніх суспільств монголами не викорінювались, а брались на озброєння і надалі використовувались для посилення централізації держави. Вочевидь, не стала винятком із цього правила й китайська державницька ідеологія. Укорінившись у монгольській державі, вона широко застосовувалась і золотоординськими ханами [4], а згодом у спотвореному вигляді - московськими князями.

Назагал дослідники відзначають, що московські князі запозичили від золотоординських ханів жорсткий порядок у галузі адміністрування, системи оподаткування та військової справи. Значення колективних органів (боярської ради та віче) у роботі державного механізму було зведено до символічного. Традиційна монгольська модель організації монаршого двору як головного органу управління державою, заснована на клановості, також була повністю сприйнята Москвою. Подібно до хана, князь був також і верховним суддею [5]. Разом зі специфікою внутрішньої політики, монгольські принципи поваги до сильнішого сусіда і необхідності завоювання слабших також стали невід'ємною частиною геополітичної стратегії московської держави. Сенс існування російської держави і сутність ï державного механізму було сформульовано Катериною II як забезпечення поваги до правителя через страх перед Богом. Історики російської геополітики, характеризуючи період іiі правління, а також загалом останню чверть XVIII - початок XIX ст. ст., послуговуються терміном «політика відкритих кордонів», маючи на увазі активне розширення російської території в цей період. Розкриваючи його суть, вони стверджують, що Росія, насамперед, прагнула «зібрати» всі колишні давньоруські землі в межах однієї держави, однак продовжувала, «як держава імперського типу», примноження своїх володінь і надалі. Зазначений період, названий західними істориками «блискавичною експансією», виявився квінтесенцією реалізації російської експансіоністської ідеології і яскраво демонструє елементи ії подібності з монгольськими засадами побудови державного ладу.

Таким чином, виходячи із зазначеного очевидно, що протягом періоду перебування Московського князівства у васальній залежності від Золотої Орди (1325-1480 pp.) основи державного ладу Монгольської імперії, спадкоємицею якої була остання, стали засадничими положеннями московської державно-правової ідеології. Богообраність правителя, попереднє освячення вищими силами всіх його рішень і дій, війна як сенс існування держави та воєнізований характер іiі механізму, цілковите протиставлення держави іншим суб'єктам міжнародних відносин - це основні з них, які стали базисом 44 
для формування російської експансіоністської ідеології, залишаючись актуальними тією чи іншою мірою і донині.

\title{
Література:
}

1. Бичурин Н. Я. История первых четырёх ханов из дома Чингисова / Н. Я. Бичурин // История монголов. - М. : Алгоритм, 2008. - С. 5-225.

2. Плано Карпини И. де. История монголов / И. де Плано Карпини // История монголов. - М. : Алгоритм, 2008. - С. 226-306.

3. Хара-Даван Э. Чингиз-хан как полководец и его наследие / Э. Хара-Даван // На стыке континентов и цивилизаций... (из опыта образования и распада империй X-XVI вв.). - М. : ИНСАН, 1996. C. 126.

4. Історія європейської цивілізації. Середньовіччя. Замки. Торговці. Поети / за ред. Умберто Еко. - Харків : Фоліо, 2018. - 763 с.

5. Исаев И. А. История государства и права России : учеб. 2-е изд., перераб. и доп. - М. : Юристъ, 2002. - 768 с.

DOI https://doi.org/10.30525/978-9934-588-92-1-9

\section{FORMATION OF NATIONAL DISTRICTS AND VILLAGE COUNCILS IN THE UKRAINIAN SSR MID-1920S - EARLY 1930S: ORGANIZATIONAL AND LEGAL SUPPORT}

\author{
Kuzmenko N. O. \\ Leading researcher \\ at the Department of European Law and International Integration \\ Institute of Legislation of the Verkhovna Rada of Ukraine \\ Kyiv, Ukraine
}

Currently, representatives of more than 130 nationalities live in Ukraine. Multinational composition of the population of the state requires a systematic and tolerant national policy, which is designed to promote harmonization of international relations, to prevent the emergence of conflicts and contradictions on ethnic ground, etc. Consequently, the interest of scientists to the historical experience of legal regulation of international relations in their own country, and especially the interest to the practice of taking into account the national factor in the process of administrativeterritorial reform becomes of particular importance. 